\title{
DOKIYA GUMANNA'S INDIVIDUAL STYLE
}

\section{Tkachenko T. I.}

\section{INTRODUCTION}

Dokiya Gumenna presents reports, essays, stories, stories, novels. The author draws attention to changes in the ratio of spiritual and material priorities in the development of the human community. However, in spite of historical conflicts, certain moral qualities remain constant criteria for personality in the doctrine of Dokiya Gumenna. The problem of ethnogenetic memory, the moral and ethical vicissitudes, appear through the literary texts of the writer. It is advisable to start the study of Dokiya Gumenna's creative work from the novel "Dity Chumaczkogo Shlyaxu", since the epic contains a lot of factual data of the author's biography. The memory of the years of life in Ukraine, the painful loss of mothers nostalgia and emotional shock - led to the emergence of a novel that covers the period from the late nineteenth century. to the 1930's. The place of events in the first and third sections of the epic is the village of Mariyka. In Kyiv, Dokiya Gumenna studied at INO (Institute of Public Education) as a student character from the second book of the novel.

Drawing on the families of Ostashenko and Sargol, the author actualizes her own memories of an excellent structure, hence, a look at the lives of her father Kuzma Gumenny's families, who prototype the image of Mercuriy Sargola, and mother of Daria Kravchenko, embodied in Odarka Ostashenko. The writer recreates her childhood in the history of Taras Sargola. The autobiographical component is decisive in the depiction of the hero. In covering the cultural outbreak of the 1920s, Dokiya Gumenna draws on personal impressions of the period. Yes, there is an indication of her stay in "Plug". If the beginning of membership in the Writers' Union for Dokiya Gumenna was a school of creative skills (evenings, discussions, meetings with meters), after publishing several truthful reports, the girl was deprived of the prospects of literary work. Only Sergiy Pylypenko spoke openly in defense of the pupil. The persecution of the young author was the beginning of the following actions of the Soviet regime: from the destruction of Dokiya Gumenna to the liquidation of MykolaSkrypnyk (the People's Commissar of Education of the USSR). It was only ten years later, in 1939, that her artistic texts were 
periodically published in periodicals. However, the shameful criticism of the story has put the writer's hopes to nothing in Ukraine. In this aspect, it is worth noting the fate of women. Emigration to Austria, later to the United States, was marked by the membership of Dokiya Gumenna in the MUR (Ukrainian Art Movement). The work in "Plug" was hampered by the dictates of Soviet power. Instead, activities in the MUR were hindered by Yuri Sherekh (deputy chairman), in particular, regarding the artistic value of the novel"Dity Chumaczkogo Shlyaxu”. In the future, every published book by Dokiya Gumenna was criticized by Valery Chaplenko, who also considered his arguments axiomatic. The uncompromising nature of the writer to herself and others has led to the disdain of Soviet colleagues and the diaspora. Dokiya Gumenna was left without material support, which affected the publication and promotion, and hence the proper evaluation of the books. In the novel "Dity Chumaczkogo Shlyaxu", the author envisaged her further destiny by presenting selfcharacterization in the images of Taras Sargola and Malvina Dubyaga: relying solely on themselves, ignoring the instructions of the powerful, fighting for the meaning of their own lives.

The writer synthesized the memories, emotions, impressions of what she saw, heard, experienced in the novel "Dity Chumaczkogo Shlyaxu", whose dominant character was defined by Dokiya Gumenna ${ }^{1}$.

\section{1. "Dity Chumaczkogo Shlyaxu” of Dokiya Gumenna}

The chronology of the work covers the events of the late nineteenth century- the first half of the twentieth century., Which took place on the territory of Ukraine. Social and political changes are portrayed through the lens of human relations. Work on the novel lasted four years (from 1942 to 1946). A form of future work was immediately found. The genre choice is due to the author's desire to cover the vicissitudes of life more than half a century of historical period. The multilinearity of the plot, embodied in the intertwining of different destinies around common national interests, the heroization of the struggle leads to the definition of the artistic text "Dity Chumaczkogo Shlyaxu" as an epic novel.

The construction of the book is cross, consistent with the shape of the cross. This assumption is supported by the opinion of Dokiya Gumenna about the messianism of the Ukrainian idea, the essence of which is in the nonviolent introduction of a certain system. Ukraine is an example of this. In addition, the writer called herself a "rebellious angel", seeing

\footnotetext{
${ }^{1}$ Мушинка М. Докія Гуменна та її «діти...» // Слово і час. 1993. - № 1. Ст. 28.
} 
in common with Christ's own destiny and sacrifice because creativity is her mission on earth, which she must carry out in spite of everything. The cross-construction of the work determines the content of each section. The first and second parts of the book are prologues and developments. The third is the graduation bond, which is the impetus for the climax the fourth part.

It is worth noting the use of framing by means of artistic imagery: the novel begins with a story about Darko, who is deprived of the opportunity to realize his innate abilities due to lack of education, stereotypes about the "woman's destiny". The last section of the book presents the heirs of Kylyna, Odarka, Mokryna, because in intellectuals Malvina (daughter of the repressed village communist Jacob Dubyaga), faith and hope are concentrated, because it is the woman who, while preserving the experience of her ancestors, has the cultural foundations of ethnicity and can provide the physical-spiritual revival of the nation.

There is a base couple in the novel "Dity Chumaczkogo Shlyaxu": the Ukrainian village is Bolshevik terror. The first and third books ("In the fragrant fields" and "Crucified the village") - an account of rural life, its traditions, customs, love of land and the destruction of the ontological foundations of the village by Soviet power. The second and fourth books ("Gates of the Future" and "Night") trace the formation of a new generation, born of a village and eliminated by a regime that will prevail in Ukraine for almost a century. Hence the interdependent spaces where the action unfolds - village and city. Initially, two places of events (Kyiv and Dryzhopilshchyna) form an antinomic pair: dynamics - static, innovation - conservatism, openness - tightness. But the common danger in the form of Soviet terror unites the former antipodes because the catastrophe of the disappearance of the Ukrainian village engulfs the city. The processes that initially take place in Mariyka later turn out to be identical events in Kyiv, eventually encompassing the entire territory of Ukraine. There are two major interrelated levels of interest in the writer in the novel: the micro-level when it comes to the individual, and the macrolevel, which covers the meaning of "nation", "people”, "statehood".

Exploring the character traits of the characters of the novel "Dity Chumaczkogo Shlyaxu", it is first of all worth paying attention to the gender category. By portraying the age of matriarchy in a series of prehistoric works, Dokiya Gumenna denies the innate traits that later became stereotypes (weakness, inertia of a woman). For the study of artistic images, one must understand the essence of the render as a 
sociocultural gender and recognize the uniqueness of the individual, regardless of physiology. The human psyche consists of the innate, inherited and acquired. Under the influence of external circumstances, it may change in the process of socialization. According to Dokiya Gumennaa, the state with a totalitarian system forms the person who needs it - disenfranchised and humble, using promises, bribery, arrests, threats.

Totalitarianism cannot be regarded as a patriarchal (sole authority) or matriarchal ("we", not "I") system, because it selects the marginal manifestations of the basic worldview constituents of the two social systems, distorting them. Its ideological core is lies. The Soviet regime produced a surrogate of people, turning them into wheels for the system to function. The only structure that governs the lives of all is the party that proclaims the truth in the last instance, despite the constant changescleansing-executions of its composition. It acts as a nameless, yet omnipotent, higher power. Hence, the organization is an individual. Ethnic identification is dominant in self-determination.

In order to subdue a person, it is first and foremost appropriate to destroy the blood link and to prevent resistance that would unite people around the national idea. In the fight against Ukraine this problem needed urgent solution, since the fact of education and wealth of Ukrainians and precedents with the "almost victory for independence" of XVI - XVIII centuries. lived in memory, leaving the danger of another explosion. The Soviet authorities have clearly defined the goal that would lead to the disappearance of the nation. The consequences of collectivization were repression, arrests, executions, mass exile, famine. Even the positive changes were distorted by Soviet methods of implementation and regulation: the free education program guaranteed the right to education for everyone, regardless of gender. But in Soviet times, social origin determined the fate of a student, an entrant, a student, an employee. Belonging to a priest or "kulak" family - one that had minimal farming, only a home - automatically deprived them of the opportunity to obtain the desired education and employment.

I had to use the established ideology of lies to get into a school, institute or find a job. The choice was small: you either lie, or die of hunger and sentencing. By depicting a kaleidoscope of characters, Dokiya Gumenna reproduces a holistic picture of the Soviet era, actualizing the features of a totalitarian system. The epic characters represent the life of that time by choosing their own destiny: a few words are enough to reveal the psychological core of a particular image and even make a historical 
excursion. The events of the novel testify to the changes in several social systems. The display of the rural system of the late nineteenth century makes one think of the sources of the nation - the Trypillya, with its female characters as the carriers of the matriarchal organization. But the village also emerges as an expression of the patriarchal order, a distorted form that became apparent during the Russian occupation, leading to the crushing influence of Russia on being Ukrainian. Dokiya Gumenna claims that a woman in the Russian Empire is the thing of a father, a husband, a son (according to the wish of the patriarch monarch). However, when it comes to Ukrainian women, ethnogenetic bonds are stronger than attempts to deform human nature. Odarka, apparently unaware of the causes, seeks beauty and something more than a certain monotonous life. Poor simple ignorant girl gave nature the gift of refined aesthetic taste. This feeling of beauty and innate dignity she retains despite the insults of the man, the forced existence in the environment of visitors to suburban ham. Her husband, MykytaSargola also has an aesthetic taste, admiring the music, feeling the urge to read the book. He is more developed through friendship with the educated VasylDemnytskyj. But the man dims his feelings. According to established norms, he should earn money, own property. The young man is suffering from stupid parental misunderstanding. Therefore, the adult Mykyta breaks his own self so that the environment does not accuse the man of publicly displaying emotions - it is weakness. Deformation of the psyche causes a distorted perception of reality: Mykyta beats his wife and cries over the book. Mykyta Sargola and Odarka Ostashenko cannot be implemented because of social stereotypes. Instead, Kyriya, the wife of Jarinej Sargola, deliberately rejects them and represents the type of "gray cardinal". The husband considers himself the head of the family, but in fact he is managed by his wife. It solves urgent problems - the education and work of children, monetary costs, the distribution of property and land holdings.

Dokiya Gumenna points to the role of ethnogenetic memory, where traits are acquired and born. Thus, in one of the female images there is a hint of the Kozak era, when the getmans, the wives of hundreds, the chieftains, the Kozaks understood politics and discussed any questions. After all, education, at least the ability to read and write, was considered mandatory for everyone. The abilities of the female members of the sexes are revealed at the genetic level in women of the next generations. The wisdom of the Ukrainian peasant is a defense against the ultimate demoralization of the people. Desperate to nature equal to the figure 
of Mokryna appears the image of Seraphym Karmalita - an elusive legend, "bandit" Duka. He was forced to play his part among strangers and strangers among his own to prove that even one person could change the world. The struggle of the young man was not to conquer, but to protect the human right to live freely in a free country. Zaporizhka Sich and the Kozaks, Koliyivshchyna, the Opryshky movement were created and acted in accordance with the actions of Seraphym. Here again is a historical projection that Dokiya Gumenna described as "wave theory". It can be concluded that the writer prioritizes aesthetic sensations, innate or acquired, ethnogenetic memory in character formation - spiritual rather than physiological. The process of "Soviet" socialization under the conditions of a totalitarian regime provoked changes in worldviews. Dokiya Gumenna choses a student life to show the types created by the Soviet system. Deprived of paralyzing fear, young people are capable of transformation and strive for improvement. The student body becomes the center and source of the formation of a nationally conscious intelligentsia, using above all the power of reason, far more powerful than the power of weapons. Expanding the INO network, the Soviet authorities initially provided the educational institutions with the best specialists who acquainted their colleagues with the scientific opinion of the world, promoted the cultural heritage and achievements of the Ukrainian ethnic group. But the totalitarian regime quickly calculated the consequences of this teaching. Mass cleansing, where nationality, in fact its protection, along with social origin, determined fate. By destroying those who teach, it is advisable to eliminate those who have already learned something. Chauvinism under the guise of internationalism became another component of the ideology of the totalitarian system ${ }^{2}$. The creation of a "Soviet man" began, which should not be distinguished by either its appearance or its inner essence. The most popular, common slogan "Take everything you can from life" - meant achieving the goal by any means. In the novel "Dity Chumaczkogo Shlyaxu" there are a large number of images of screws of the Soviet system. Among them, it is appropriate to pay attention to the figure of a talented ambitious student. Tamara Sagaidachna is an exemplary creation of a new ideology. The intelligent woman has indeed achieved great success, but only at the expense of women's charms, becoming a prostitute for officials. The image of Borys Mykytchuk is completely identical to the previous

${ }^{2}$ Костюк Г. На перехрестях життя та історії: до 70-річчя літ. діяльності Докії Гуменної // Сучасність. 1975. - Ч. 3, берез. Ст. 52. 
one. For the sake of material gain, he combined arrogance with cunning, in the absence of moral and mental qualities. Dokiya Gumenna depicts a type of person who can be controlled, intimidated, emphasizing the method of Soviet power that cloned free-lance robots. The totalitarian regime created an idol for the youth - sex, theft, servant, hypocrite, who would be a model of prosperity and career upswing. Both, Borys and Tamara, regardless of gender, perform the functions of prostitutes, making the goods their own lives.Instead, the Soviet authorities encouraged such active behavior in the pursuit of ambition.

Opposites to the "cogs of the system" are images of the Ukrainian intelligentsia, including the literary elite. But Dokiya Gumennaa emphasizes first and foremost the thoughts and actions of ordinary people who have preserved and protected the national identity and freedom of at least the personal component of life. They form the spiritual core of the nation. The figure of Kylyna synthesizes the traits inherent in ethnic mothers - Odarka, Mokryna, Xrystya. The image of this woman is a projection of the image of a mummy in a matriarchal family. Kylyna absorbed their sense of beauty, dignity, sincerity, spiritual strength, national consciousness and added knowledge gained through education. Another way of life, depicted from the beginning, which opposes the leveling of personality, is attracted by the inner meaning. All external events are reflected in the work of the soul of Taras Sargola. An introvert cannot be recognized in a totalitarian society. Introspection is dangerous for the Soviet authorities - a constant state of introverts that helps one to understand oneself, to recognize own uniqueness. Taras inherited his mother's vulnerability. Paper becomes his friend and arrestee, who helps to communicate, to make love, to be creative. Taras explodes inside, but must be calm outside: becoming a servant of the system, he will destroy himself; if an open fight begins, the system will eliminate it. The only way out is to retain their knowledge and feelings to find like-minded people for the sake of passing on to the future generation the core of the nation. Given the position of the Soviet authorities, Taras is probably passive.

However, the author's semantics of the feminine passivity category and the masculine activity category destroy the stereotypical interpretation. Dokiya Gumenna emphasizes the "liberation from the tribute of the sex" when the presence of the defining features of the human being - the priority of the spiritual over the material, justice, mercy and honesty - does not depend on the bodily shell. 
In the second and fourth parts of the novel "Dity Chumaczkogo Shlyaxu”, the vision of Dokiya Gumenna's artistic life of the 20-30s of the twentieth century is reproduced, since Taras belongs to the cohort of masters of the artistic word.

Retrospective display of vicissitudes is clearly subjective, contains the author's precise characteristics of contemporary figures, phenomena and events of the cultural environment. In the novel "Misto" (1927), Valeryan Podmogylnyj outlines certain tendencies of the literary process of the 1920s. Particularly interesting is the embodied projection of oral speech in the manner of writing: Vasylko (G. Kosynka) in a speech reveals the skill of a novelist, picks every word, reaching the gradation of content. In the portrayal of Taras Sargola, as a novice writer, Dokiya Gumenna has shed light on her own creative path. She uses an autobiography episode, picking a nickname for herself.It is appropriate to note the peculiarity of the display of the artistic process of the 20-30's of the twentieth century. Two parts of the novel, devoted to the cultural component of social life, form a kind of antithesis. If irony prevails in the second book, "Gates of the Future", sarcasm and grotesque in "Night". This change in presentation is related to the destruction of the cultural environment. In the novel "Misto" ValeryanPodmogylny focuses only on literature, describing an area of culture that is directly related to the central character of the work (StepanRadchenko). Dokiya Gumenna seeks to embrace the cultural process as a whole. After all, Ukrainianization contributed to the progress and activation of all creative forces: a variety of circles and unions ("Gart", "Plug”, "Lanka”), experimental theater "Berezil” (Les Kurbas), revived book printing, the opportunity to openly discuss the topics of cultural and political development. Despite the "snow Parnassus", which was characterized by intellectual refinement, and the "red podium", which became a haven for numerous graphomans, everyone had the right to state their position aloud. The controversy "Where do you climb, snot?" (Yakovenko, Pylypenko-Xvylovyi, Zerov) has highlighted the significant issues for the Ukrainian nation. The diversity and richness of the 1920s. it produces the effect of the speed of cultural development, which gives events an instant expression. Dokiya Gumenna aims to cover as many phenomena and figures as possible. Therefore, the second part - the artistic kaleidoscope - strikingly contrasts with the fourth section. The "Crucified Village" not only reproduces the process of collectivization in the village and its consequences, but also performs the function of semantic graduation, culminating in the "Night". Freedom of thought turned into a 
dictatorship of the party. Reprisals, arrests, executions, intimidation, insanity have become a means of fighting the "enemies of the people". It is worth paying attention to changes in the literary environment. Despite the censorship and fear, the characters of "Gates of the Future" express their opinions aloud, publicly openly. Subsequently, the only source of information is rumor or whispering. It is in this way that Taras learns of Khvylovy's suicide, the imprisonment of Krynychka (E. Pluzhnyk), the Head's emigration. Irony and benevolent humor disappear. Grotesque acquires a marginal expression in the screening of the "Soviet basket" the Union of Writers. Facelessness is a priority feature of the "co-author of the totalitarian regime". The prototype (O.Kornichuk) in the work of art does not appear by individuality, but by the type (Mykytchuk), in which Dokiya Gumenna emphasizes the characteristics inherent in pseudomanders, who act as images of pseudoscientists. The writer points to a constant feature of Mykytchuk's behavior - artificiality. It covers all manifestations of his nature: emotions, speech, gestures. If in the second part, Mykytchuk differs from the intellectual elite, his classmates and acquaintances, then in the fourth book this feature becomes commonplace, typical of the vast majority of characters. Boris's denunciations are transformed into a rule of cooperation with the Soviet regime through personal images. Dokiya Gumennane resorts to an allegory that expresses the aforementioned metamorphoses. Thus, in the center of creativity national culture - there are representatives of fauna: lions, foxes, cats, horses, swallows, leopards, deer.

Literary art for showing spiritual break is not accidentally selected. In order to eliminate ethnic identity, it was necessary to eradicate the Ukrainian language. The distorted word is the dominant feature of human degradation. The lexicon of every language is a reflection of a worldshaped, centuries-old world of a distinct nation. Language chauvinism is the destruction of the Ukrainian ethnic group. Reproducing the changes taking place in the cohort of the masters of the artistic word, the writer uses a means of contrast through antinomic pairs, which can be established by comparing the sections "Gates of the Future" and "Night". Opposites represent changes in literary, cultural and political life: freedom - fear, naturalness - artificiality, aloud - whisper, nationalism chauvinism, development and progress - static and regression, ridiculing spirit - denunciations and arrests, uniqueness - unification. Dokiya Gumennaoutlines the most important tendencies of the 20's - 30's of the twentieth century. 
In the novel-epic "Dity Chumaczkogo Shlyaxu" a number of problems were raised, such as: issues of national identification, the role of ethnogenetic memory, the confrontation of man and system, spiritual and material under the Soviet era of totalitarianism. For the most part, however, literary critics emphasize the documentary value of the work, determining the novel's social-political aspect.

The village and the city are in fact the main participants in the events when the image of the "crucified village" is a metaphor for Ukrainian Calvary. Characterizing Taras as "not a fighter" and contrasting him with the active Seraphym, Dokiya Gumenna emphasizes that the internal corrects the external. Therefore, Taras did not submit to the system, on the contrary, he conquered it by retaining its essence.

Psychology of images, attention to detail, creation with the help of strokes of a holistic picture of the day represent the skill of Dokiya Gumenna. However, the axiomatic nature of the critic's findings makes sense of the work, negating the importance of interpretations of other literary critics, the author's position and the subjective reception of the reader. Ukrainian researcher $\mathrm{P}$. Soroka denied the dominance of the social aspect in the novel "Dity Chumaczkogo Shlyaxu". However, he only noted the existence of philosophical problems without specifying them ${ }^{3}$.

With the synthesis of all components of the artistic text, as well as the features of the author's worldview, one can determine the conceptual core of the work - showing the eternal uncompromising constant struggle of the forces of darkness and light. Gumenna says that evil will never create good. This is in my novel. But no one saw. The battle of good and evil continues every minute, gaining external embodiment, though it is the source of the person who has the likeness given by the Lord. Good and evil, produced by Him, are indispensable components of the individual's nature. The victory of light depends on the individual and preserves his / her inner world.

\section{2. "Velyke Czabe” of Dokiya Gumenna}

The cycle of works by Dokiya Gumenna are dedicated to the origins. The formation of the human society from the Ice Age represents at the same time the evolution and degradation of culture and civilization. Artists notice the greatest achievements and shortcomings of a person who seeks to reach the world. Interest in historical topics was the

3 Гуменна Д. Діти Чумацького шляху: Роман у 4-х кн. Київ: Український центр духовної культури, 1998. Ст. 487. 
beginning of popularization in the Ukrainian literature of the genre of prehistoric story, which is distinguished by its scientific value, because it contains archeological and cultural data. An important element of the text is artistic thought and subjective interpretation. That is why the work "Bless you, Mother!" Dokiya Gumenna defined the genre as a fairy tale essay. So it is possible to define a cycle of artistic texts of the writer of prehistoric issues, namely: "Velyke Czabe", "Past floats to the future", "Family album”, "Bless you, Mother!”, “Golden plow”. The author offers her own interpretation of the fairy tale. She denies the presence of fantastic elements in her works, instead emphasizing the relativity of knowledge, the limited human capacity to claim the truth of the assumptions:historical work is only approaching the opening of the day. Science and art interact to help grasp every historical period in terms of past, present and future. Dokiya Gumenna denies all the rejections in the fantastically utopian work, defines her artistic texts of this cycle by fiction on a scientific background.Her "prehistoric fiction" is thoughtful and artistic, not fictional.

The story "Velyke Czabe" was published in 1952. The work on the artistic text lasted several years before its publication and has undergone many changes. The writer sought to achieve the expressiveness of each character through an individual psychological characteristics. Archeological findings, historical facts, scientific theories have formed the basis on which a complete artistic text is constructed, an arena for the unfolding of events. Careful reconstruction of the past ensures the accuracy of the perception depicted in the work. The choice of the Trypillya is not accidental. From the time of discovery (1893) by $\mathrm{V}$. Xvoyko archaeological expeditions have been going on to reveal the main stages of formation and the mystery of the death of one of the most developed civilizations. Dokiya Gumenna sees the importance of Trypillyan culture for Ukrainians. If historians pay attention to the territorial location of settlements, material findings, ethnographers - to the patterned symbolism of objects, folklorists - to the ritual elements of customs, then the writer points out the ideological continuity that demonstrates the defining features of the Ukrainian mentality ${ }^{4}$.

The author covers various issues, reaching a complete reproduction of a certain historical period. The main problem is the coexistence of two opposing types of worldview and relevant community arrangements.

\footnotetext{
${ }^{4}$ Космос древньої України: Трипілля - Троянь: Мітологія. Філософія. Етногенез: VI тис. до н. е. І тис. н. е. / Упоряд., вступ. ст. В. Довгич. Київ: Індо-Свропа, 1992. Ст. 167.
} 
The writer points out that the priority of the matriarchal and patriarchal system of community organization depends not only on the economic and political structure of society, above all - the progress of each member of the community in the process of socialization, the influence of established norms on the human psyche and behavior.

The controversy over the species (patriarchy / matriarchy) of the primary social organization has continued since the beginning of science. By the middle of the nineteenth century axiomatic recognized the opinion of Plato and Aristotle about the primordial patriarchal system on which the state was formed.

However, using data from archeology, ethnology and mythology, I. Bachofen ("Maternal Law”, 1861) and L. Morgan (“Ancient Society”, 1877) proved the primacy of the matriarchal order. Subsequently, F. Engels and E. Taylor defended the historical priority of the mother race. The problem of the patriarchal and matriarchal in the world view was explored by prominent anthropologists, philosophers and psychologists (E. Fromm, Margaret Mead, Karen Gorny, Simone de Beauvoir, O. Kulchytsky). But scientists are still debating the primacy of the feminine / masculine social order.

In Ukraine, particular attention is paid to the definition of the ruling system in the days of the pro-Ukrainian Trypillian culture (from VI thousand to I millennium BC). Most archaeologists, historians, and culturologists (Natalia Polonskaya-Vasylenko, M. Grushevsky, Ye. Krychevsky, TetianaPassek) argue for the matriarchy of ancient Trypillya society, substantiating their assumptions with the findings. The artistic interpretation in the literary text was an attempt to get to know the spiritual life of Ukrainian ancestors, though the achievements of scientists were undoubtedly the impetus for this. Drawing on the confrontation of, in fact, the coexistence of two social systems in the Tripillya, Dokiya Gumenna projected the matriarchy / patriarchy into the primordial interaction of feminine / masculine types of outlook. The two dominant concepts are dominated by power, feminine and masculine reception, which is different. In masculine images, Gumenna embodies the changes that take place in a person through the whim of power. Recognizing physical strength in a universal way to attain one's purpose saves one's mind and feelings. Blind aggression prevails, which destroys the priority of spiritual value. A completely different power is possessed by a woman ${ }^{5}$.

\footnotetext{
${ }^{5}$ Friedan Betty. The Feminine Mystique. New York: Norton, 1963. P. 13.
} 
The writer emphasizes that feminine power governs through the power of words, where the mighty gods are powerless. The constant presence of magic in human life gives the woman a sacred status. The misunderstanding, therefore, of the mysteriousness of feminine power causes men to fear it and provoke, from helplessness, the use of physical force. By focusing on this feminine trait, Dokiya Gumenna addresses the problem of the existence of a distinct female language.

It should be noted that the words of the orders, spells, ritual songs of that time, probably make up the vocabulary of women's speech, which today is seeking to revive, reconstruct or re-create. Text is the body of a woman. In the word it embodies its rhythm, its bodily sensuality. Because of this, most ritual activities are performed by a woman naked. Hence, there is a synthesis of the power of the spirit and the power of the body, which is realized in the word-cry-prayer. The gift of communicating with the surreal world is potentially possessed by all women. The priority of physicality in language is projected on the vision of the universe as a female being and used in the interpretation of the Mother who embodies life (Lada-Kupala) and death (Marena-Mara). Therefore, the power of the word can be resurrected or destroyed. Words act as indicators of social order, which is noticeable at the semantic level. This explains the changes of the Virgin Lada to Santa Lada, Dana to the Dniester, and more. Words can reflect the system of community organization.Gynecocracy implies a democratic construction, which is enlightened in the names of the genera in the plural (pitchforks, mulberries, turkeys), in the definition of deities (mother-earth-water-sun-fire-shore-grain-cow-copper-tree of life); andrococracy manifests itself in a hierarchy - a sole power in the singular (king, priest, father, husband) ${ }^{6}$.

Dokiya Gumenna draws attention to how two kinds of power determine attitudes toward nature. The matriarchal community interacts with flora and fauna representatives at all times, even possessing some of their properties. The natural element and the woman are interdependent. Relations between them are based on partnership. Nature acts as an assistant and advisor to man in all its affairs. Human life is associated with the elements - water, fire, earth. Purity of fire - burning of the dead, jumping through the fire on the holiday of Kupala - requires a decent life. The sister villas manage the rain. The river Rus is the ancestor of one of the matriarchal communities, where, apparently, the Ruthenians originate, given the etymology of the name. The ability to

\footnotetext{
${ }^{6}$ The Feminist Critique of Language: a reader. New York: Routledge, 1998. P. 256.
} 
give birth enhances the magic power of words. Communication with nature, a feminine gift to feel it - the primordial forms of animism, totemism, fetishism. Material things made from the gifts of nature are also important for a woman. They also have a soul. That is why every jug, furnace and pelvis must be protected. The ritual contains an aesthetic component: protection is the appearance of patterns where the characters created by the woman have magical power. Man, fearing unmanageable elements, seeks to conquer nature. If a woman asks for respect, the man destroys and destroys, not only to facilitate daily life, but also to prove his superiority, an unattainable greatness. The patriarchal world neglects what it does not understand.

Gumenna contrasts nature and civilization. The writer points out that the amount of natural resources is not inexhaustible. Therefore, the problem of environmental catastrophe becomes dangerously urgent. Dokiya Gumenna highlights the slogans of ecofeminism that emphasize the affinity of women and nature: both feel each other and try to be heard by the patriarchal world.Man treats nature not as sisterhood, but property, the extent of which is directly proportional to the status in the patriarchal community. The masculine device gives the property undeniable authority. This concept encompasses, besides nature, half of humanity women. No wonder slavery is a product of patriarchy. The musculoskeletal system provokes constant competition and envy. The relentless thirst for accumulation, which is satisfied through violence and robbery for the sake of the title of the Great Czabe, the Ruler, the King, leaves no time for reflection on spiritual degradation.

The patriarchy devalues the value of selfless human relationships, the observance and sanctity of the ancient customs of the race. For the matriarch of ancestral tradition, mutual respect, love between blood and non-blood, members of not only the community, but the inhabitants of the world are generally axiomatic.

Therefore, the dominant in the feminine community is the right of collective property, which prevents property disputes. Unlike the masculine system, living beings do not belong to anyone because of their feminine priority - freedom. Free from birth people, animals, birds, plants are devoid of the cult of things and slave humiliating obedience. By depicting the struggle of matriarchal and patriarchal worldviews, Dokiya Gumenna reproduces the antinomy of the collective and the private, first and foremost, in relation to material achievements. The writer combines two opposing forms of life on the example of the 
central characters of the work. Despite Luka's desire for accumulation, he finds himself in a spiritual vacuum, his ambition, driven by the primacy of his personal prime, compels the pursuit of new knowledge ${ }^{7}$.

In accordance with the forms of ownership, ways of obtaining it, the figure of the head of the genus emerges. Patriarchy identifies power with property. Leaders are selected by the amount of wealth. The life of each member of the community depends on the head who sets the rules of coexistence, according to which disobedience and rebellion are punished by death.

Taboo-invented community leaders help manage obedient cohabitants. The matrimony of the matrimonial race deserves respect and obedience due to its moral virtues. The head is recognized not by the richest, but by a worthy, experienced and wise man. Maternal love does not require obedience in exchange for service. For the sake of happiness, a mummy can violate dogma, because it protects the equality of rights and aspirations of every person.

Depicting the excellent organization of the masculine and feminine communities, the author points to their dominants: if patriarchal society is always hierarchical, then the matriarchal order is based on the principles of parity. In accordance with the specifics of the community and the figure of the leader, the writer projects between the external structure of society and the internal priorities of the person. In the masculine outlook, the determinant is individualism, the ultimate manifestation of which is selfishness, and the core of the feminine position is cordocentrism. Both features of different systems are characteristic of the mentality of Ukrainians. Given the different worldviews of men and women, Dokiya Gumenna explores two opposing views on community development. The musculoskeletal system chooses the easiest way to get what you want - a war because of the superiority of men in physical strength, which is why they invented weapons. Subsequently, the struggle between neighboring, alien communities becomes a total all-consuming massacre of all against all. The patriarchal worldview is despised by compromise. An act, therefore, of acknowledging one's mistake is considered the unacceptable weakness worthy of contempt. The fanatical pursuit of absolute power makes it possible to avoid thinking about the number of victims for the purpose. Probably tyranny and dictatorship are the heirs of this ideology. The physical destruction or subjugation of the victorious causes the partial or complete degradation of the victor when double

\footnotetext{
${ }^{7}$ Гуменна Д. Велике Цабе: казка-есей. Нью-Йорк: Слово, 1952. Ст. 154.
} 
standards of conduct and rules of coexistence are formed. Patriarchal creation - mounds confirm the death category ${ }^{8}$.

The dead are buried with his "property": with his murdered wives. The observable hierarchy determines the absolute priority of the Czabe, the Monarch, the Ruler, embodied in a strict dictatorship. The desires, dreams, thoughts and lives of the rest weigh nothing. The matriarchal principle of organizing society proclaims peace (an alternative to war) as a priority basis for the coexistence of communities.

The matriarchy promotes mutual intercourse for the sake of love, peace and the continuation of being human, plants, animals. The main principle in the fight is protection, not attack. Tolerance in dealing with an invader demonstrates respect for every living being, regardless of his or her views, beliefs, or actions. Therefore, life is the central category of matriarchal ideology. The decisive keynote in the Czabe is the danger of loss of peace. The beginning of the change of peace to war is embodied in the transition from matrilocal to patrilocal marriage.

The matriarchy and the patriarchate, as two worldview systems, oppose each other. Dokiya Gumenna establishes clear oppositions: heart mind, power of speech - force of arms, nature - civilization, collective individual, parity - hierarchy, peace - war, life - death. Despite the author's sympathy for the matriarchal system, the writer points out the advantages and disadvantages of both social entities. This is evidenced by the choice of the figure of the protagonist. Luka is a stork. Our folk beliefs that a stork - a small god. He combines both features. Adult archaeologist Luke Savur thanks to his birth to a once-saved infant ancestor, and to the profession - an inherited desire to open up new perspectives on culture, science and technology.

Man of the twentieth century archaeologist Luka has a greatgrandfather Luka and great-grandmother Jagilka. With two distinct worldviews (masculine and feminine) in mind, the Ukrainian Luka Savur first of all acts as the heir to the Trypillyan civilization, examining her achievements, protecting and preserving the memory of her ancestors. By engaging in such framing, Dokiya Gumenna projects the past into the present. Therefore, the sleep technique used is not an additional element, but a dominant element in the interpretation of the story.

\footnotetext{
${ }^{8}$ Гапон Н. Гендер у гуманітарному дискурсі. Львів: Літопис, 2002. Ст. 187.
} 


\section{CONCLUSIONS}

Dokiya Gumennaa's works are characterized by a characteristic inherent in the feminine outlook: if a man builds a new one, rejecting the old, then the woman opposes oblivion, tries to preserve the best of the past, hence providing a connection of generations. An important role in the artistic texts of Dokiya Gumenna is played by a detail that also expresses a feminine perception of reality.In the descriptions of clothing, dishes, interiors there is a feminine trait of their perception. The author painstakingly depicts the decoration of things, but emphasizes not only the magical power of amulets or crossbows with modern patterns: for a man the main thing is the practical use of the object, but for the woman the aestheticization of each thing is important, the constant focus on beauty, the actualization of the sensual.

Sincerity is characteristic of women's writing: the emotional freedom displayed in the manner of presentation the author's feminine identification. It gives the special "sense of feeling" by which Dokiya Gumenna recreates reality.

The best of the old should be drawn to create the perfect new. Mutual respect and understanding are the basic principles of development, for violence produces only violence, which ultimately causes death without resurrection or rebirth. Probably, the author hints at biarchy, which takes into account the advantages of matriarchal and patriarchal order. A special feature of the doctrine of the Gumenna is the peculiar framing of the artistic text embodied in the element of the dream with genetic memory: "I am all my ancestors, the whole nation [16.IX.51]".

\section{SUMMARY}

The article devotes to the study of prose of Dokiya Gumenna. Attention focuses on highlighting the peculiarities of the individual style of the writer, which splits the personality aspect into the disclosure of the disturbed problems, the reproduction of character characters, axiological accents.

The paper clarifies the unique author's world perception that determines the content and formal text organization (rhythmized prose, excursion, anticipation, stream of consciousness, internal monologue, diversity of speech, especially silence, reflection, ontological core, the sense of epigraphs, refrain and dedication, the variation of the rate of presentation, open final), the choice of artistic figurative and expressive means (symbol, contrast, parallelism and antithesis, metaphor, elliptic and rhetorical constructs), which determine the artistic phenomenon of the author. 


\section{REFERENCES}

1. Гапон Н. Гендер у гуманітарному дискурсі. Львів: Літопис, $2002.310 \mathrm{c}$.

2.Гуменна Д. Велике Цабе: казка-есей. Нью-Йорк: Слово, $1952.156 \mathrm{c}$.

3. Гуменна Д. Діти Чумацького шляху: Роман у 4-х кн. Київ: Український центр духовної культури, 1998. 576с.

4. Космос древньої України: Трипілля - Троянь: Мітологія. Філософія. Етногенез: VI тис. до н .е. - I тис. н. е. / Упоряд., вступ. ст. В. Довгич. Київ: Індо-Свропа, 1992.303 с.

5. Костюк, Г. На перехрестях життя та історії: до 70-річчя літ. діяльності Докії Гуменної // Сучасність. 1975. - Ч. 3, берез. С. 52-71; Ч. 4, квіт. С. 50-75.

6. Мушинка М. Докія Гуменна та iї «діти...»// Слово i час. 1993. - № 1. С. 26-35.

7. The Feminist Critique of Language: a reader. New York: Routledge,1998. $368 \mathrm{p}$.

8. Friedan Betty. The Feminine Mystique. New York: Norton, 1963. $384 \mathrm{p}$.

\section{Information about the author:}

Tkachenko T. I.,

Doctor of Philology, Associate Professor at the Department

of Slovenian Philology and Journalism, Academic and Scientific Institute of Philology and Journalism,

V. I. Vernadsky Taurida National University (TNU)

33, John McCain str., Kyiv, 01042, Ukraine 